\title{
ACCESS TO SAFE WATER AND THE HUMAN DEVELOPMENT QUANDARY IN AFRICA: IMPLICATIONS OF A RIGHTS-BASED APPROACH
}

\author{
Dejo Olowu \\ LLM, LLM, PG, JSD \\ Research Professor \\ Public Law and Legal Philosophy \\ North-West University, Mafikeng
}

\section{SUMMARY}

Despite formal and concerted commitments by African governments to achieve universal access to clean water through various initiatives since 2000, access to clean drinking water remains a continuous challenge for human development in SubSaharan Africa. While some states have achieved some progress, achieving largescale availability of safe water remains a humanitarian crisis in much of Africa. The underpinning premise of this article is that a comprehensive and integrated approach can ensure the sustainability of expanding access to drinking water and sanitation while facilitating economic growth and human development. This article thus investigates the institutional, political, economic, and communal constraints in achieving expanded access to clean water among vast African populations. What are the roles and responsibilities that the civil society and local government agencies have to assume (a) to ensure that local water users and their organizations can assume their responsibilities for sustainable water resource management; and (b) to make sure that water is indeed considered a human right, and not in the least for those who have little or no access to power and influence: women and other underprivileged groups in local societies? Beyond the question of funding, what will be the role and place of a rights-based approach to the underlying structural challenges of participatory planning; ownership of the distribution processes as well as local accountability, all of which determine the sustainability of development programming pertaining to water? This article proffers a series of trajectories within a right-based approaches framework and accentuates how pragmatic responses to the foregoing questions could contribute to the policy responses necessary to ensure the realization of a well-managed regime of water access, distribution, and management in Africa.

INTRODUCTION

Without mincing words, lack of progress in improving global access to water, sanitation and hygiene is inhibiting progress in human development. Across Africa, half of all rural households do not have access to clean drinking water; they must rely on water sources that may be unhealthy. The situation is better in urban areas, where a substantial part of the population is covered. Yet more than half of city and town dwellers do not have a tap in 
their premises. ${ }^{1}$ UNICEF and World Health Organisation (WHO) reported recently that despite the efforts made by some countries, approximately 340 million people in Africa are without access to safe drinking water and only 26 countries will reach the water target under the Millennium Development Goals, $2000 .^{2}$ The question of poor access to readily accessible drinking water is further compounded by lack of effective water-quality testing even where water is available. ${ }^{3}$

The implications of lack of clean water (and, by extension, access to adequate sanitation) for human development are widespread. Young children die from dehydration and malnutrition, results of suffering from diarrheal illnesses that could be prevented by clean water and good hygiene. ${ }^{4}$ Diseases such as cholera are spread rampantly during the wet season. Women and young girls, who are the major role-players in accessing and carrying water, are prevented from doing income-generating work or attending school, as the majority of their day is often spent walking miles for their daily water needs. They are also at an increased risk for violence since they travel such great distances from their villages on a daily basis, and are even at risk when they must go to the edge of the village to find a private place to relieve themselves. The irony is that Africa has abundant fresh water: large lakes, big rivers, vast wetlands and limited but widespread groundwater. Yet, only $4 \%$ of the continent's available fresh water is currently being used. ${ }^{5}$

However, the premise of this article assumes a more profound reach beyond the dominant approach to water discourses that conceives the provision of safe water and the guarantees of its access as the sole responsibility of the state. This article seeks to develop the idea of responsibility in its broader sense and what this could mean in terms of water rights and responsibility at the grassroots levels of every African municipal jurisdiction, such as local communities, local households and their collectives. Responsibility is used here in the broader sense of being in charge of one's own behaviour and actions, at the same time being able to account for the effects of such behaviours and actions to others. In SubSaharan Africa, where an estimated 340 million people do not have access to safe drinking water, the need for increased cooperation between stakeholders in improving water security cannot be overemphasized. While access to water is a human right, water consumers across the board have a shared responsibility for advancing new ideas and strategies geared towards the efficient use of water resources. Indeed, there is a need to forge and strengthen symbiotic relationships in mobilizing financial and human

Winkler The Human Tight to Water (2012) 3; and WaterAid Everyone, Everywhere: A Vision for Water, Sanitation and Hygiene Post-2015 (London 2013) 14.

2 UNICEF and World Health Organization (WHO) A Snapshot of Drinking Water and Sanitation in Africa (New York 2008) iv.

3 Awuah, Nyarko, Owusu and Osei-Bonsu "Small Town Water Quality" 2009248 Desalination 453.

4 Metwally, Ibrahim, Saad and Abu El-Ela "Improving the Roles of Rural Women in Health and Environmental Issues" 2006 16(2) International Journal of Environmental Health Research 133.

5 Bouwer "Integrated Water Management: Emerging Issues and Challenges" 200045 Agricultural Water Management 217; and Faurès and Santini Water and the Rural Poor: Interventions for Improving Livelihoods in Sub-Saharan Africa (2008). 
resources, skills integration and capacity building. While great strides have been made towards this end, most notably through the global ascendancy of the Integrated Water Resources Management (IWRM) approach, ${ }^{6}$ it is clear that there are yet opportunities for even greater cooperation at multiple levels of decision-making.

The significance of considering such local responsibilities stems from the recurring failure of a large number of development projects during the past few decades. Laban forcefully demonstrated that the long-term and sustainable impact of programme interventions in the water sector depends for an important part on the sense of ownership and the degree of accountability that local people take in the way water resources are managed in their community and for the activities that are needed to use and maintain that resource. ${ }^{7}$ In many cases, the people will not assume such accountability as they do not feel the activity and/or their results to be really theirs (ownership), being something provided temporarily by an outside institution (usually a government agency) that does not meet their real priorities or longer-term interests.

This article accentuates the advantages of shared action when stakeholders have a shared idea and commit to shared purposes by focussing on three key partnerships. In particular, the article stresses the importance of a bottom-up approach in facilitating comprehensive water management, as local water users are empowered to become active decision-makers who manage their own quality of life. This requires a rational framework of collaboration and an enabling environment, which brings the comparative strengths of various stakeholders to bear in the sustainable management of water resources.

There can be no gainsaying the direct and indirect linkages between access to water and human development for the ordinary African. The UNDP and numerous other analysts have done so much to demonstrate that better access to water and sanitation could act as the reagent for a massive advancement in human development, creating opportunities for gains in public health, education and economic growth. ${ }^{8}$ Sadly, the realities on ground have been the squandering of opportunities on such a large scale. ${ }^{9}$

6 Jeffrey and Gearey "Integrated Water Resources Management: Lost on the Road from Ambition to Realisation?" 2006 53(1) Water Science \& Technology 1; Biswas "Integrated Water Resources Management: Is it Working?" 2008 24(1) International Journal of Water Resources Development 5; and Sokolov "Integrated Water Resources Management" in Madramooto and Dukhovny (eds) Water and Food Security in Central Asia (2011) 37.

7 Laban "Accountability and Rights in Right-based Approaches for Local Water Governance" 2007 23(2) International Journal of Water Resources Development 355, 356.

8 UNDP Human Development Report 2006 - Beyond Scarcity: Power, Poverty and the Global Water Crisis (New York 2006); Laban 2007 23(2) International Journal of Water Resources Development 357; and Winkler The Human Right to Water 5; and WaterAid Everyone, Everywhere: A Vision for Water, Sanitation and Hygiene Post-2015 3.

9 Olowu "Privatisation and Water Governance in Africa: Implications of a Rights-based Approach" 2008 4(1) TD: Journal of Transdisciplinary Research in Southern Africa 59. 


\section{AFRICAN EXPERIENCES IN THE GLOBAL CON- TEXT OF ACCESS TO SAFE DRINKING WATER}

\section{Sectoral reforms and the water-privatization model in Africa}

From the time of independence into the 1980 s, water provision was mainly a state activity, carried out by governments through public utilities such as water boards. These were financed through government budgets, relying mainly on donor support and taxation. Since they were not run on profitmaking basis, tariffs were minimal for piped connections. Some of those without house connections in towns and in some rural communities got water from public standpipes, mostly free of charge. However, these publicly run systems left out millions of people. Economic crisis and the austerity policies promoted by the World Bank and IMF obliged African governments to cut back spending on public utilities, including water, and in a number of cases to privatize existing facilities. The expectation was that the private sector, mainly multinational water companies, will come in and take over public water companies, running them as profit-making entities while investing and expanding the network. However, this expectation did not materialize. Private investors did not find the water sector in Africa financially attractive as the returns were not enough to justify their investments. ${ }^{10}$

In the 1990s, foreign companies were offered greater incentives, such as tax holidays and the full repatriation of profits, in an effort to draw them into the sector. Even then, private investors generally preferred Asia and Latin America to sub-Saharan Africa. Africa thus suffered from decades of underinvestment in water facilities. Given this, and the poor management that afflicted utilities in many African countries, the largely publicly-run sector could not maintain existing levels of service, let alone make new connections. ${ }^{11}$ As part of the push to promote private participation in the water sector in Africa and other developing regions, "cost recovery" became an increasingly common practice. For the private companies themselves, the application of higher water tariffs and user fees was central to turning a profit. However, for the public utilities as well, increasing tariffs was also seen as a way to stem financial losses or increase resources for further investment. $^{12}$

Arguments in favour of privatization are largely based on the logic that transnational corporations are ideally suited and capable of managing and distributing water because of the ability to tap readily into large amounts of private equity, efficient management structure, access to cutting-edge technology, ability to recover the full cost of distribution, and the capacity to eliminate market-distorting subsidies. Moreover, it is expected that the sale

Olowu 2008 4(1) TD: Journal of Transdisciplinary Research in Southern Africa 71.

1 Dovi "Bringing Water to Africa's Poor" 2007 21(3) Africa Renewal 7; and Biswas 2008 24(1) International Journal of Water Resources Development 5.

12 World Bank "Cost Recovery, Equity and Efficiency in Water Tariffs: Evidence from African Utilities" Africa Infrastructure Country Diagnostic, Working Paper 7, May 2008 (Washington DC 2009) 9-10. 
and purchase of water in free and open markets will determine the opportunity to fix the "true price" of water, based on the forces of supply and demand, and rationalize water consumption, that is, users will automatically adjust their demand and modulate their utilization based on their ability to pay, thereby conserving water. ${ }^{13}$ Arguments propounded are consistent with the neoliberal economic model that privileges market-based approaches, which increasingly dominate the global economy and are governed by a set of universal rules generated and agreed upon by states, international financial organizations, and transnational corporations. Advocates of privatization contend that the technology, effort, and cost involved in the treatment and distribution of water from its raw and non-purified state to potable standards bring water on a par with any other industrial product. Hence, it is the prerogative of the private corporations to treat water as an industrial commodity that would enable them to fix a price that is market dependent. After all, private firms operate on the principle of profitmaximization and not on any altruistic objectives, and neither are they motivated by larger public-policy goals such as enabling universal access or reducing water-related public-health crises. Besides, the principal motivation of profits, private sector involvement in water treatment and distribution is encouraged due to the presumed ancillary advantages, such as full-cost recovery, efficient management and distribution, technology improvement, and alleviating government-budgetary pressures. ${ }^{14}$ After all, many public utilities, such as electricity and gas, telecommunications, roads, railways, garbage collection and disposal, and urban sanitation are fully privatized and function rather effectively in advanced industrialized states. Privatization of water would be a mere extension of the policy successes in these other areas to the domain of water resources. More than three-quarters of the water-distribution system in many parts of the developed world are already privatised. The growing move towards privatization of public utilities has therefore largely resulted from the combination of external market and international institutional pressure. ${ }^{15}$

For opponents of the privatization model, access to water is a basic entitlement that humans and animals automatically gain by being a part of the earth's ecosystem, and therefore, private corporations cannot create new enclosures and deny or restrict access based on ability to pay. They also contend that privatization of water creates new barriers to the access of common-pool resources, which allows only a small group of capital owners to exploit a public good without any regard for the environmental consequences or concerns and profit at the expense of the already impoverished. ${ }^{16}$

For many people who never had access to piped water or had previously gotten water from private carters who charged exorbitant prices, the new

\footnotetext{
Ibid.

Biswas 2008 24(1) International Journal of Water Resources Development 12.

15 Drobak "A Comment on Privatization and Democratization" 200650 Saint Louis University Law Journal 783.

16 Shiva Earth Democracy: Justice, Sustainability, and Peace (2005) 6 and 15.
} 
tariffs may have seemed worthy. Nevertheless, for many of Africa's poorest, the costs were prohibitive. ${ }^{17}$

\section{Government-led initiatives and responses}

African leaders had declared their commitment to achieving universal access to clean water, through their development blueprint, the New Partnership for Africa's Development (NEPAD), 2001, and through their support for the Millennium Development Goals (MDGs), which were adopted by world leaders in 2000. The seventh MDG's objective is to cut in half by 2015 the proportion of people without sustainable access to safe drinking water and basic sanitation. In Sub-Saharan Africa, the population of people having access to improved drinking water increased from $56 \%$ in 1990 to $64 \%$ in 2006, while increases in coverage are not keeping pace with population growth. More so, the MDG target remains very distant. ${ }^{18}$ The struggle to reach the MDG's, however, obscures the broader objectives of the African Water Vision 2025 that sets strident targets and extended periods for meeting all the development challenges of the African water sector. These challenges range from water governance (including the perimeters of ownership and accountability), meeting urgent needs, improving water intelligence and, most importantly, strengthening access to finances.

Under the auspices of the African Union (AU) Assembly of Heads of State and Government established the African Ministers' Council on Water (AMCOW) in Abuja, Nigeria, in 2002, primarily to promote cooperation, security, social and economic development and poverty eradication among member states through the effective management of the continent's water resources and provision of water-supply services. At the 11th ordinary session of the AU Assembly, in 2008, the Heads of State and Government of the $\mathrm{AU}$ agreed on commitments to accelerate the attainment of water and sanitation goals in Africa and directed AMCOW to develop and follow up comprehensive implementation strategies for these commitments. ${ }^{20}$

Among its other enunciated initiatives, AMCOW spearheads the Africa Water Week; the Africa Water Journal; the Africa Groundwater Commission; the Water, Climate and Development Programme (WACDEP); the Rural Water Supply and Sanitation Initiative (RWSSI); the AfricaSan; as well as the African Ministers' Initiative for WASH (AMIWASH). ${ }^{21}$

Access to water is indeed high on the African development and policy agenda, as scarce water resources face increasing risks from climate warming and a burgeoning urban population. ${ }^{22}$ Indeed, water resources in Africa's growing urban centres are extremely overburdened, and prolonged

17 Olowu 2008 4(1) TD: Journal of Transdisciplinary Research in Southern Africa 69.

18 UNICEF and World Health Organization (WHO) A Snapshot of Drinking Water and Sanitation in Africa 10.

19 Donkor "Preface" 2007 1(1) African Water Journal 1.

20 AMCOW Status Report on the Application of Integrated Approaches to Water Resources Management in Africa (Addis Ababa 2012) 2.

21 See AMCOW "Initiatives" http://www.amcow-online.org/ (accessed 2013-05-17).

22 AMCOW Status Report on the Application of Integrated Approaches to Water Resources Management in Africa 3. 
service disruptions are the order of the day in most cities, as water authorities struggle to deliver this vital resource. With the tightening of public budgets in many of these countries, supply-side management will no longer be a feasible strategy to meet the ever-increasing demand for water. The critical water-supply shortage has resulted in a significant increase in the exploitation of groundwater sources, primarily through illegal deep welldigging in densely populated areas, and a heavy reliance on water vendors who, according to some studies, charge as much as ten times the price of locally supplied water. Some countries, such as Senegal, Gabon, Uganda and South Africa, are significantly increasing the number of new water connections and expanding delivery in urban areas, through both public and private investments. Senegal, for instance, was reported by the UN in a March 2011 assessment of progress towards the MDGs, as being on track to achieving the water and sanitation goals through a national investment programme financed with donor money.

As is common with public services, water consumption has been characterized by free riding at the local level. While expressing their right to safe drinking water, there has been a tendency for local water users to excuse themselves of responsibility in terms of efficient water use and ensuring the resource's sustainability. As such, excessive water consumption is rampant, while late and non-bill payment is prevalent, particularly among low-income households. However, some empirical studies on this issue suggest that non-payment is primarily due to ratepayers' inability rather than unwillingness to pay for services. ${ }^{24}$ In their defence, local water users bemoan the service provider's lack of accountability to ratepayers and lack of transparency - particularly with regard to management of funds. ${ }^{25}$ However, the significant increase in water demand in urban areas necessitates cooperation between water users and local government in devising and committing to effective water-demand management strategies.

Africa faces a number of constraints in achieving expanded access to clean water. These include an insufficient number of skilled personnel and effective institutions. In some countries, water scarcity or pollution also pose particular challenges. The most common hindrance is the limited resources available to most countries. Inadequate financing is the single most important factor affecting the continent's fresh water-delivery abilities ${ }^{26}$ From where will the money come? Donor assistance is one source as we have seen in the case of Senegal. However, donors are likely to provide only a

23 UN Department for Social and Economic Affairs Assessing Development Strategies to Achieve the MDGs in the Republic of Senegal (New York 2011) 7.

24 Bouwer 200045 Agricultural Water Management 217; Raje, Dhobe and Deshpande "Consumer's Willingness to Pay More for Municipal Supplied Water: A Case Study" 2002 42(3) Ecological Economics 391; and Fjeldstad "What has Trust Got to do With it? Nonpayment of Service Charges in Local Authorities in South Africa" 2004 42(4) The Journal of Modern African Studies 539.

25 World Bank Africa Infrastructure Country Diagnostic, Working Paper 7, May 200811.

26 Dovi 2007 21(3) Africa Renewal 8. 
portion of the estimated $\$ 5$ billion needed annually to achieve the MDG target. $^{27}$

Independent assessors estimate that total budgetary spending in the water and sanitation sectors in Sub-Saharan Africa is currently around $\$ 800$ million per annum. This amount could likely be increased to $\$ 2.5$ billion through "cost-recovery" measures by service providers (charging users for water) and financial mobilization by local communities. Governments could also be able to increase their own budgetary allocations somewhat. ${ }^{28}$ In addition, a number of countries, at the instance of the World Bank and the International Monetary Fund (IMF), have persistently sought to enlist private investment in expanding water facilities. ${ }^{29}$

In its Human Development Report 2006, which essentially concerned water and water-related poverty, the UNDP had contended that, in seeking to expand access to clean water, "decisions about the appropriate publicprivate mix have to be taken case by case on [the basis of] local values and conditions". ${ }^{30}$ In most developing countries, such as are found in SubSaharan Africa, the need to ensure universal access to water and sanitation has resulted in the design of tariff structures that do not reflect the full cost of providing these services. Largely, this has deterred private sector involvement in the water sector and subsequently, technology and skills transfer, as private entities would need to charge full marginal costs to ensure a reasonable return on their capital investments. ${ }^{31}$ In the absence of financial and technical support from the private sector, developing country governments grapple with infrastructure backlogs, limited managerial capacity, and challenges in the maintenance of existing infrastructure. With the deepening of the water crisis, the importance of forging mutually beneficial public-private partnerships in water-resources management is becoming increasingly recognized. In addition, water-resources management has been largely relegated to water professionals, with minimal cooperation from those in other sectors. However, because water is a vital social and economic benefit to all water consumers, the need for crosssectoral cooperation is critical, now more than ever. In addition to enhanced inter-sectoral integration, there is a compelling need for the establishment of a platform that facilitates cross-transfer of skills, knowledge and expertise between water professionals and those outside the "water-box".

Without mincing words, African governments have the responsibility to reach the more than 300 million people who are currently deprived of improved drinking water. This necessitates the putting in place the right water policies to embrace the participation of the private sector in water

27 AMCOW Status Report on the Application of Integrated Approaches to Water Resources Management in Africa 39; and WaterAid Everyone, Everywhere: A Vision for Water, Sanitation and Hygiene Post-2015 10.

28 WaterAid Everyone, Everywhere: A Vision for Water, Sanitation and Hygiene Post-2015 10.

29 Camdessus and Winpenny Financing Water for All: Report of the World Panel on Financing Water Infrastructure (Marseille, World Water Council 2003) 6-7; and WaterAid Everyone, Everywhere: A Vision for Water, Sanitation and Hygiene Post-2015 9.

30 UNDP Human Development Report 2006 - Beyond Scarcity: Power, Poverty and the Global Water Crisis 89.

31 World Bank Africa Infrastructure Country Diagnostic, Working Paper 7, May 200813. 
provision. In the absence of such credible policies, the amelioration of Africa's water crisis would be forlorn.

Despite the negative image held by some commentators that African public utilities are inherently inefficient and can only be improved by the introduction of private owners or contractors, a quick survey of the publiclyowned water utilities in some African countries shows that some are efficiently run using local management structures.

\section{Kenya}

In Kenya, for example, a water policy developed in 1999 led to improvements in the quality of water from the country's public system, raised revenue collection, and brought more boreholes to rural communities. Legislation enacted in 2002 on water decentralized the management of water resources and delivery in Kenya. Local public companies were formed to manage water in localities. They largely achieved their goal of increasing the number of customers served with improved water by $50 \%$ and reducing water wastage by over $40 \%$, without raising tariffs. ${ }^{32}$ Yet, admittedly, even in Kenya, equitable access - between the urban areas where the infrastructure caters for the planned and the unplanned settlements - remains a challenge.

\section{South Africa}

Overall, South Africa has achieved remarkable progress in expanding access to clean water. Under the defunct "apartheid" system, about one-third of the population, overwhelmingly in the country's previously segregated black communities, did not have access to safe water. However, when the African National Congress (ANC) came to power in 1994, the new Constitution proclaimed access to water as a basic human right. By 2004, about $88 \%$ of the population had access to clean water. ${ }^{33}$

As a matter of policy, all those with access to piped water are entitled to receive 25 litres per day at no charge. However, beyond that threshold, users must pay, at a steeply graduated rate. Both private companies and local public water utilities have strictly enforced the cost-recovery practice, affecting poor households most severely. In 2002, the Johannesburg-based Rural Development Services Network, a non-governmental organization, estimated that some 10 million people had their water supply cut off at one point or another over the previous eight years for failing to pay their bills. Two years earlier, a major cholera outbreak swept the province of KwaZuluNatal, claiming some 300 people. Health officials found that many people in the most affected areas had resorted to using water from polluted rivers and lakes nearby, because they had been cut off from their water taps for non-

32 See Onjala Managing Water Scarcity in Kenya: Industrial Response to Tariffs and Regulatory Enforcement (PhD Dissertation, Roskilde University, Denmark, 2002) 141-146; and Sammy Water Privatization in Kenya (2004) 3.

33 Dovi 2007 21(3) Africa Renewal 9. 
payment of bills. The Government responded by installing public standpipes in many low-income communities and by introducing low flat rates. ${ }^{34}$

Currently, a budget of R4.34 billion had been allocated for new interim water-supply programme (IWSP), aimed at addressing the backlogs in local water-related service delivery over the Medium-Term Expenditure Framework period, which would be funded through the Municipal Water Infrastructure Grant. Under South Africa's latest National Water Resource Strategy 2013, capital investment in new water and sanitation infrastructure for the entire value chain, including the refurbishment of existing infrastructure, was projected to require some R670 billion over the next ten years, or R67 billion a year - making it the largest investment by any government in the water sector in Africa. The NWRS 2013 would ensure greater equity in water-resource allocation, enhanced water-governance processes, intensified institutional oversight, and improved overall waterresource management. ${ }^{35}$

\section{Ghana}

Ghana attempted to solve its difficulties by bringing in new, outside managers for its water utility. The hope was that they would operate it more efficiently and along commercial lines. The public water utility, the Ghana Water Company Ltd. (GWCL), had previously been able to provide water to about half of the country's population of 20 million. However, it started losing money for a variety of reasons, including unpaid bills and illegal connections. As a result, it could not make any significant repairs or further extend the system. ${ }^{36}$

In 2005, officials in Accra estimated that the company had lost half of its daily delivery of 450 million litres through leakages from old pipes. At the urging of the World Bank, the Government restructured the GWCL. In 2001, GWCL had increased water tariffs by more than $90 \%$. To make the GWCL more financially viable and to attract potential investors, the Government also wrote off $\$ 100$ million in debts that the company owed. In 2005, the Government managed to secure a $\$ 103$ million grant from the World Bank, and bilateral donors provided an additional $\$ 17$ million. The Government hoped that the fresh money would enable the GWCL to replace obsolete equipment and repair leaking pipes. It also set a goal of installing some 50,000 new household connections and 350 public standpipes by 2011 in Ghana's main towns. ${ }^{37}$

34 Folifac "National Water Policies and Water Services at the Extremes: What Challenges must be Faced in Bridging the Gap? Learning from the South Africa Experience" 2007 1(1) African Water Journal 8.

35 Greve "DWA to Roll out R4.3bn Interim Water Supply Programme" 21 May 2013 Engineering News http://www.engineeringnews.co.za/article/dwa-to-roll-out-r43bn-interimwater-supply-programme-2013-05-21 (accessed 2013-11-13).

36 Nkrumah "Challenges to Urban Water Management in Ghana: Making Public-private Partnerships Work" 2004 1(2) Ghana Journal of Development Studies 85.

37 Fonseca, Batchelor, Moriarty, Naafs, Snehalatha, Reddy, Nyarko, Klutse, Pezon, Potter and Verhoeven A Multi-dimensional Framework for Costing Sustainable Water and Sanitation Services in Low-income Settings: Lessons from Collecting Actual Life Cycle Costs for Rural 
As a condition for the World Bank grant, the Government had to agree to bring in a private water company to manage the GWCL. Through an international tender, Aqua Vitens Rand Ltd. (AVRL), a joint subsidiary of two multinational water companies, Vittens of the Netherlands and Rand Water of South Africa, won a five-year management contract, and began running the GWCL's delivery system in January 2006. Maintenance of the system and investments in new equipment and extensions continued to be the responsibility of the public company. Years later, many customers are still looking at dry pipes. GWCL officials blame Ghana's energy crisis, the result of low water levels in the reservoir of the Akosombo hydroelectric dam. AVRL's managers emphasise investment problems. Local critics of the AVRL contract agree that investment is important, but go further to question the wisdom of bringing in outside managers. The World Bank insists that improved management and investment are essential. ${ }^{38}$

The summation struck by the few scenarios considered thus far is to illustrate the perception that Sub-Saharan Africa lags behind other regions on both water and sanitation, with only 19 countries on-track to meet the MDG-water target. In part, this is due to low investment by national governments and donors, as well as by the private sector, with the funding to meet the target nowhere near what is required. Performance in the sector is also affected by the low capacity of national and local agencies, many of which suffer from weak leadership and planning capability, staffing and skills gaps, and poorly allocated budgets. ${ }^{39}$

Summarizing the trade-off between expanded access and costs, the UNDP's Human Development Report 2006 stated, "The challenge for all providers, public and private, is to extend access and overcome the price disadvantage faced by poor households". 40

\section{AFRICA'S WATER CRISIS AND STRATEGIES FOR IMPROVED ACCESS AND MANAGEMENT}

For many African governments, the challenge is not only about finding more money for vital investments. It is also acquiring the technical expertise to use the resources most effectively and the institutions capable of managing them properly. In countries such as Uganda or Mozambique, each with a population of about 20 million, it was once estimated that achieving the MDG goal will require installing some 1,000 new point sources of hand-dug wells and drilled boreholes fitted with hand pumps, plus 30 piped systems every year, as well as establishing utility operators in five major cities and 15 secondary cities. To get to that point, such countries will need professionals with the skills to plan, budget, design, supervise and construct the facilities,

and Peri-urban Areas of Ghana, Burkina Faso, Mozambique and Andhra Pradesh (The 38 Hague: IRC International Water and Sanitation Centre, 2010).

WaterAid Off-track, Off-target: Why Investment in Water, Sanitation and Hygiene is not Reaching Those Who need it Most (London 2011); and WaterAid Everyone, Everywhere: A Vision for Water, Sanitation and Hygiene Post-2015 18.

40 UNDP Human Development Report 2006 - Beyond Scarcity: Power, Poverty and the Global Water Crisis 89. 
as well as engineering, drilling and construction equipment. In some African countries, especially those emerging from conflict, such capacity is simply not available. About a third of African countries have the capacity to implement investments, if direct financing can be secured. However, in the rest, such capacity needs to be built, perhaps as a component of project financing.

Evidently, most grants come with formal and informal conditions attached which force African governments to hire experts - consultants, technical management and designers - from donor countries to implement the projects. This in turn makes it hard for affected African countries to retain national water professionals. Disregarding local expertise in the implementation of such projects inevitably makes the water sector unattractive, compelling many professionals to leave. To address this problem, the UNWater/Africa Network - which comprises various UN agencies, the NEPAD Secretariat and the African Development Bank - set up a directory of African water experts. By making it easier for such experts to serve in other African countries, the initiative will not only help foster regional integration, but also enhance the long-term maintenance of water projects on the continent.

Beyond the issues of wherewithal to guarantee access to safe drinking water for all is the question of popular distrust among the end users of water. As already mentioned, there is a culture of pervading wariness against local water authorities engendered through lack of accountability and transparency. There appears to be a strong perception of misappropriation of ratepayers' funds, as evidenced by poor service delivery. ${ }^{41}$

It was the acknowledgment of the cumulative and inevitable linkages among water authorities, water providers, and water users that engendered the Integrated Water Resources Management (IWRM) approach which has become the reference point in water-governance and water-security discourses over the past two decades. ${ }^{42}$

Originally known as the Dublin Principles in reference to the International Conference on Water and the Environment in Dublin in 1992, they were later refined and incorporated into the agenda adopted by the United Nations Conference on Environment and Development (UNCED) in Rio de Janeiro, 1992. ${ }^{43}$ With their emphasis on the tripartite concerns of economic efficiency, social equity, and environmental sustainability, the Dublin-Rio Water Principles continue to define the central theme of contemporary water resources management. ${ }^{44}$ In a widely accepted manner of championing integrated water-resources management as a major component of its technical programme, the Global Water Partnership (GWP) defines IWRM as "a process that promotes the co-ordinated development and management of water, land and related resources, in order to maximize the resultant

41 Camdessus and Winpenny Financing Water for All: Report of the World Panel on Financing Water Infrastructure 10; and Drobak 200650 Saint Louis University Law Journal 787.

42 Sokolov in Madramooto and Dukhovny (eds) Water and Food Security in Central Asia 41.

43 Ibid.

44 Shah and Van Koppen "Is India Ripe for Integrated Water Resources Management? Fitting Water Policy to National Development Context" 2006 41(31) Economic and Political Weekly 3413. 
economic and social welfare in an equitable manner without compromising the sustainability of vital ecosystems".

Analysing the ample literature on IWRM across the world, Biswas put together a list of 41 items encompassed by the integration ethos of IWRM. ${ }^{46}$ For our purposes, however, the aggregation of IWRM entails the existence of:

(a) a national water policy so that there is a cohesive, well-understood normative framework to guide all players in the sector;

(b) a water law and regulatory framework for coordinated action for sustainable water-resources management;

(c) the recognition of the river basin as the unit of water- and land-resources planning and management and creation of river-basin organizations in place of territorial/functional departments;

(d) treating water as an economic good by pricing water resource as well as services, especially outside-lifeline uses, to reflect its scarcity value so that it is efficiently used and allocated to high value uses;

(e) the creation of water rights, preferably tradable, by instituting a system of water-withdrawal permits; and

(f) participatory water-resource management with involvement of women so that water becomes everybody's business.

IWRM is significant for the thrust of this article in that it assumes a holistic approach which sets a framework for collaboration - both vertically (among stakeholders at multiple levels of decision-making) and horizontally (among agencies, non-governmental organizations, state departments, and the public and private sector). The central premise of IWRM is therefore that peoples' initiatives and management of their own quality of life should be at the centre of planning and action. It stresses a bottom-up approach with the human being and his/her household becoming a focal point in water, sanitation and hygiene decision-making, and emphasizes collaboration between government and civil society.

In several African countries, adopting IWRM has essentially meant implementing variations of the above compendium. AMCOW's 2012 report found that 18 of African countries have IWRM plans under implementation, and five out of the 16 that responded to AMCOW's survey, had IWRM plans or were in the process of developing them. ${ }^{47}$ In South Africa, for instance, the latest water policy and water law provided for establishing state ownership of all water, the institution of water use rights through withdrawal permits, pricing of water in all uses, and transferable water permits to encourage trade in water rights. ${ }^{48}$ Embracing the above, as implied in the IWRM discourse, may help alleviate water poverty by improving access to

45 Global Water Partnership. Integrated water-resources management. TAC Background Papers No. 4 (Stockholm: GWP Secretariat, 2000) 22.

46 Biswas 2008 24(1) International Journal of Water Resources Development 10-11.

47 AMCOW Status Report on the Application of Integrated Approaches to Water Resources Management in Africa 2.

48 Folifac 2007 1(1) African Water Journal 8. 
water and minimizing environmental ill-effects associated with current patterns of water-resources development in developing countries like Ethiopia. ${ }^{49}$ Among several issues, the IWRM involves working to improve the potency and effectiveness of three pillars of the water institutional framework, namely, water policies, water laws, and water administration in managing the water affairs of a society through a new emphasis on direct water-demand management.

With IWRM having assumed so much popularity among development experts, policy planners, and the bevy of interested commentators, should we not begin to query why the situation of access to safe drinking water remains parlous after more than two decades since the notion of IWRM debuted in Africa?

Several studies have demonstrated that water poverty - the lack of access to water for productive and consumptive needs for communities - is not always an outcome of the scarcity of water and/or the failure of water institutions and policies to counter it but rather the failure of multiple role actors to build the capacity for, and to exert the capacity for responsibilities in the management of a scarce commodity such as water. ${ }^{51}$

Capacity building is vital in empowering local communities to become agents of change. To this end, the service provider should facilitate training of community representatives in leadership, communication and management. Furthermore, the service provider should involve these representatives in water-resources planning, development and management as a step towards increasing transparency. In turn, these representatives would be tasked with formulating and championing water-conservation campaigns. They would also provide regular feedback to community members on issues such as bill payment, water quality and efficient water usages, as well as facilitating information exchange between community members and the service provider through workshops and meetings. In addition, community representatives would also act as the primary channel of communication in reporting customer complaints.

The establishment of a sustainable partnership requires that both parties participate in formulating mutually beneficial objectives and in the development of clear communication networks. Each party should then be able to hold the other accountable for failure to adhere to these objectives and mechanisms, and should be put in place to deal with divergence from the approved goals. It is imperative for water authorities to embark on recognizable institutional reforms geared towards enhancing the service provider's functional capabilities, operational strengths and institutional readiness to handle water challenges - both present and in the future. In particular, there is need for an improvement in infrastructure planning and

49 Ayenew "Some Improper Water Resources Utilization Practices and Environmental Problems in the Ethiopian Rift" 2007 1(1) African Water Journal 83.

50 Cofie and Drechsel "Water for Food in the Cities: The Growing Paradigm of Irrigated (Peri) Urban Agriculture and its Struggle in Sub-Saharan Africa" 2007 1(1) African Water Journal 26.

51 Shah and Van Koppen 2006 41(31) Economic and Political Weekly 3414; and Laban 2007 23(2) International Journal of Water Resources Development 356; and Biswas 2008 24(1) International Journal of Water Resources Development 13-14. 
management and, in some cases, a review of the water-pricing structure, to align water prices with the cost of supply. In addition, there is a need for increased efficiency in revenue collection and managing unauthorized water usage.

A central beginning in facilitating cooperation between local water users and water authorities is the creation of mutual trust and understanding, through constant dialogue aimed at addressing the above issues in a transparent manner. Water authorities should use this platform to discuss water-access challenges by providing statistics on average daily demand for water, pumping capacity versus demand, service-disruption timetables and water quality, among other issues. Most importantly, the service provider should use this platform to educate water consumers on their responsibility in the water-provision cycle. As noted above, human rights come with responsibilities and as such, it is imperative for water users, with the support of the service provider, to assume an active role in the formulation and implementation of effective water-management strategies. Indeed, there is an urgent need for water users to adjust their consumption preferences and find ways of utilizing the resource in a more efficient manner. While water rationing is a common water-conservation strategy employed by the service provider, if consumers resume excessive water use as soon as the water service is restored, it is largely ineffective.

As Laban precisely demonstrated, a majority of the cases reflecting the failure of water management is due to the fact that the essential helpful atmosphere was not created by duty-bearers and beneficiaries so that central preconditions under which local people could assume responsibility for their water-resource use and management were not fulfilled. ${ }^{52}$ Both these duty-bearers and beneficiaries have a major responsibility. In many significant ways, therefore a rights-based approach would emphasise the indispensable accountability and responsibilities of government, suppliers and end-users.

\section{WHAT IS THE VALUE-ADDED MAGNITUDE OF A RIGHTS-BASED APPROACH IN AFRICA'S WATER DISCOURSES?}

Forging a comprehensive water-resources management strategy requires a holistic approach that fosters cross-sectoral collaboration. As the IWRM concept highlights, a fragmented approach is not an effective strategy in tackling water issues. In the same year that the MDGs were adopted, the Water Supply and Sanitation Collaborative Council (WSSCC) had, in its Vision 21, emphasized the need for collaborative and participatory strategies, including placing community and country action at the centre - to prepare their own vision and develop an action programme to achieve this. The core principles of Vision 21 is that this collaborative multi-stakeholders approach would serve as a means for all role actors to gain mutual understanding of the several aspects critical to water issues, and empower them to discuss strategies from different angles. Indeed, the merging of

${ }^{52}$ Laban, above note 7, 359. 
professionals from different sectors promotes the development of new ideas on how issues can be tackled differently.

At the heart of the Vision 21 is the acknowledgement of hygiene, water and sanitation as a human right, and relating it to human development, the elimination of poverty, environmental sustainability and the integrated management of water resources. ${ }^{53}$ In the logic of Vision 21,

"Poverty is a severe blockage to human development. By any definition, inadequate water, sanitation and hygiene contribute significantly to poverty. Poor people themselves consistently place lack of water as one of their main poverty indicators. In view of their huge mutual effects, it is therefore essential that water, sanitation and hygiene are included in human development and poverty elimination programmes."

The human right to water is fundamental for life and health. Sufficient and safe water is thus a precondition for the realization of all human rights. The UN Committee on Economic Social Cultural Rights (CESCR) in its different General Comments has held that the right to water is one of the fundamental rights needed for the realization of all other rights guaranteed in the International Covenant on Economic Social Cultural Rights. The right to water has also been explicitly recognized in the General Comment No. 15 adopted on 26 November 2002 by the CESCR. The World Water Council, the 3rd World Water Forum, the Global Water Partnership, the Dublin Statement on Water and Sustainable Development, and the United Nations have all endorsed the view that the "human right to water is indispensable for leading a life in human dignity", and access to water and sanitation is a "prerequisite for the realization of other human rights". ${ }^{5}$

What then is a rights-based approach? What is the benefit of a rightsbased approach? How can a rights-based approach be translated into practical tools for planning, monitoring and evaluating projects and programmes aimed at resolving or preventing resource-related conflicts?

Without specifically highlighting "human rights", much of current development policy and practice adopts a rights-based approach in terms of focus, emphases and objectives. Among widely known range of examples are land-title issues; poverty reduction; gender disparity; governance; corruption; and judicial reform policies of some major multilateral institutions such as the World Bank. ${ }^{56}$ Many other international non-governmental organizations and international development agencies have also applied the rights-based approach in their development efforts, while the approach has also been canvassed in the writings of many scholars. ${ }^{57}$

53 Water Supply and Sanitation Collaborative Council (WSSCC), Vision 21: Water, Sanitation and Global Wellbeing (Geneva, WHO, 2000) 1.

54 Water Supply and Sanitation Collaborative Council (WSSCC), Vision 21: Water, Sanitation and Global Wellbeing 6.

55 Camdessus and Winpenny Financing Water for All: Report of the World Panel on Financing Water Infrastructure vii.

56 World Bank Focus on Voice, Empowerment, Participation, Transparency, Accountability (Washington, DC: World Bank, 2000).

57 Lundström "Human Rights-based Approaches to Development Cooperation, HIV/AIDS, and Food Security" 200729 Human Rights Quarterly 460, 475-476; and Olowu An Integrative Rights-based Approach to Human Development in Africa (2009) 15-16. 
Developing rights-based approaches has been a journey of discovery: exploring new ideas, challenging established beliefs and ways of working and searching for solutions beyond the boundaries of conventional discourses and human-rights work. It has been an intensive process of experimentation, questioning and learning. While there is broad consensus on the theoretical foundations of a rights-based approach, ${ }^{58}$ there are yet no practical blueprints on how resource-related conflicts should become rightsbased. Every intervention therefore has to adopt its own analysis of what a rights-based approach implies in its social, political and cultural contexts.

The distinct mark of a rights-based approach, as against other approaches to social issues, is its contingency upon legal foundations. These foundations are to be located within the relevant international, regional and national arrangements. It has to be conceded, however, that asserting these platforms as the basis for a rights-based approach is not as cut-and-dried as it sounds. This is so because the pace of ratification of human-rights treaties varies from state to state, and even where states have ratified those instruments, very few take cogent steps at domesticating them. ${ }^{59}$ Similarly, where African governments give formal recognition to human rights, it is often a case of more rhetoric than substance, homily without action. The effect of this scenario is a noticeable limitation in the efficacy of the human rights involved.

Within the UN system, the International Bill of Rights provides the cornerstone of the rights-based approach to human development along with all the instruments mentioned in this article capable of adding depth and vigour. ${ }^{60}$ Properly applied, the critical goals and targets of Africa's development agenda can be assured under a rights-based approach to water (and of course, sanitation) such as would generate the following scenarios:

(a) education: children can go to school instead of collecting water, fewer girls drop out, and educational outcomes improve;

(b) health: Fewer children die, people are healthier and less vulnerable to disease, and health facilities are safer and less crowded;

(c) gender equality: Women are free to work and grow food rather than collecting water, and are less vulnerable to abuse and violence;

(d) poverty reduction: People are healthier and more productive, workplaces are safer, and businesses can flourish; and

(e) environmental sustainability: Natural resources are better shared and protected for future generations. ${ }^{61}$

This article assumes that unhindered access to safe water is a defining characteristic of any society in which human beings live and a component in their development. Through activities that are centred on participatory rights, designed and implemented with the participation of all stakeholders, it will

\footnotetext{
Olowu An Integrative Rights-based Approach to Human Development in Africa 15-16.

Baah Human Rights in Africa: The Conflict of Implementation (2000) 41.

Olowu An Integrative Rights-based Approach to Human Development in Africa 15-16.

61 WaterAid Everyone, Everywhere: A Vision for Water, Sanitation and Hygiene Post-2015 35.
} 
become possible to achieve the long-term goal of facilitating equitable access, distribution and management of water resources in both the local and national spheres.

Rights-based programming uses a wide range of methods to achieve concrete and sustainable results for people and their rights. This approach works to get duty-bearers to fulfil their obligations, to support people in claiming their rights, to fight discrimination, and to strengthen equality and inclusion. The choice of appropriate action depends on the opportunities in a particular country, on the rights or issues that are being addressed and on the organization's mandate and expertise. To combat child sexual abuse in Cameroon, for example, an organization may advocate for changes in legislation, utilize mass media to educate the public about sexual abuse, train social workers and law-enforcement personnel in child-protection methods and establish mechanisms for listening to children in schools or in shelters for street and working children.

A rights-based approach to resource-based conflicts will therefore require (a) long- and short-term goals with a clear focus on people and their rights. This further requires analysing problems, causes and responsibilities at local, national and international levels; (b) working together with other governmental and non-governmental agencies towards common rightsbased goals; (c) equity and non-discrimination - concentrating on the worst rights violations and paying particular attention to the most marginalized people; (d) accountability - strengthening the accountability of duty bearers for human rights at all levels, in this case, the government concerned. This should be achieved through a combination of direct action, changes in laws, policies and equitable resource allocations, changes in institutional rules and practices and changing attitudes and behaviours; and (e) participation supporting rights-holders (children, women, adults and civil society institutions, etcetera) to realize their rights.

The rights-based approach envisages that the effective protection and promotion of human rights can become vital instrumentality in ensuring the accountability of governments, a platform that will in turn support ongoing efforts aimed at promoting socio-economic justice, bedrock for the establishment of truly participatory and democratic economies. In other words, a rights-based approach to resources-based conflict has the capacity to widen the ambits of existing and emerging liberal democratic regimes around Africa, and thus, to allow the interests of marginalized groups like peasants, workers, women, youths, the deprived, people with disabilities, the unemployed, and people living with HIV/AIDS to become relevant issues in mainstream political and socio-economic discourses.

The core of the advocacy here is that when human rights guarantees and concerted mechanisms of social accountability are synergized, the space for positive cooperative action is amplified and incentives for water-policy failure reduced. Public and local institutions seen as legitimate in multiple domains are therefore crucial in moderating failure risk during rapid social, economic and political transitions such as Africa has witnessed since the 1990s. Establishing credible and transparent mechanisms for popular participation and deliberation in water-resource management decisions will help build 
trust and common understanding about alternative courses of action and reduce the likelihood of destructive decline.

\section{CONCLUSION}

Africa's water sector faces many challenges. Principally, the need to improve efficiency in service delivery. Increasing populations and uncertain climatic changes will pose heavy demands on water resources on Africa and Africans in the nearest future. Holistic approaches and integrated management principles will be necessary to develop sustainable systems and prevent catastrophes. Indeed, African water-policy discussions are deeply, and often unduly, influenced by emerging global discourses on how developing countries can put their water sectors in order. The fashionable embrace of the IWRM model across Africa provokes further rigorous interrogation along the lines suggested in this article.

This article has demonstrated that the way forward towards achieving wider access to clean water includes strengthening institutional capacity and governance at all levels, promoting more technology transfer, mobilizing more financial resources and scaling up good practices and lessons learned - all processes anchored on the centrality of a rights-based agenda that squarely places human beings at the centre of all water planning and programming.

One cannot agree more with the UNDP when it posited in 2006 that

"Human rights are not optional extras. Nor are they a voluntary legal provision to be embraced or abandoned on the whim of individual governments. They are binding obligations that reflect universal values and entail responsibilities on the part of governments. Yet the human right to water is violated with impunity on a widespread and systematic basis - and it is the human rights of the poor that are subject to the gravest abuse."

Far from being an ex-cathedra pronouncement on all the dynamics that should inform the improvement of access to water in the fulfilment of the MDG target on water as well as scaling up the human-development performance of African states beyond the MDGs, this article would have served its purpose if it stimulates further intellectual discussions.

62 UNDP Human Development Report 2006 - Beyond Scarcity: Power, Poverty and the Global Water Crisis 4. 